\title{
Use of E-resources by the Students and Researchers of Faculty of Arts, Annamalai University
}

\author{
S. Thanuskodi \\ Library \& Information Science Wing, Directorate of Distance Education, Annamalai University, 608002, Annamalai Nagar \\ thanuskodi_s@yahoo.com
}

\begin{abstract}
The study aimed at finding the use of e-resources by the post graduate students and research scholars of Faculty of Arts in the Annamalai University. A questionnaire was distributed among the Research scholars and Post-Graduate Students to collect desired data. A total of 200 questionnaires were distributed to the selected sample of Faculty of Arts; 180 valid samples were collected. The study found that the majority of users are aware about the availability of e-resources. The result reveals that $47.78 \%$ of respondents want to access only electronic version whereas only $32.78 \%$ users want to read the printed journals but $19.44 \%$ respondents want to use both electronic and printed version. Majority of the respondents $76.66 \%$ use e-resources for writing papers. The analysis reveals that many of the respondents search e-resources through linking facility available on the library website
\end{abstract}

Keywords Faculty of Arts, E-resources, Internet, E-mail, Library website, Search Engines, File Format, User study

\section{Introduction}

The twentieth century was shaped by sweeping changes in communication technologies. The emergence and use of information technology is the century's most significant development affecting scholarly communication. The application of computers to information processing has brought several products and services to the scenes. Consequently, the academic community has undergone tremendous changes during these years, assuming new dimensions influenced by technology-driven applications. Libraries have witnessed a great metamorphosis in recent years both in their collection development and in their service structures. Thus Libraries are using technology to improve the management of scholarly information to strengthen and speed access to scholarly information not held locally. Over the last several years a significant transformation has been noticed in collection development policies and practices. Print medium is increasingly giving way to the electronic form of materials (Sharma, 2009) ${ }^{1}$. Ani $(2008)^{2}$ states that "the transition from print to electronic medium apart from resulting in a growth of electronic information, has provided users with new tools and applications for information seeking and retrieval. Electronic resources are invaluable research tools that complement the print-based resources in a traditional library setting.

Commenting on the advantages of electronic resources,

* Corresponding author:

thanuskodi_s@yahoo.com (S. Thanuskodi)

Published online at http://journal.sapub.org/library

Copyright (C) 2012 Scientific \& Academic Publishing. All Rights Reserved
Dadzie $(2007)^{3}$ writes that electronic resources are invaluable research tools that complement the print - based resources in a traditional library setting. Their advantages, according to her include: access to information that might be restricted to the user due to geographical location or finances, access to more current information, and provision of extensive links to additional resources related contents. This rapid emergence and development of electronic information technologies therefore makes it possible to envision radically different ways of organizing the collections and services the library has traditionally provided. While libraries approach a crisis point in financing collection development, these new technologies offer possible ways to mitigate costs and revolutionize ways to access information. Naidu (2007) ${ }^{4}$ also finds that speedy publication and availability on the desktop are the key advantages that attract research scholars.

\section{Electronic Resources}

Electronic resources are the electronic representation of information. There are available in various forms like e-books, digital libraries, online journal magazine, e-learning tutors and on line test. Because of the effective presentation with multimedia tools, these e-resources have become the source of information. Electronic resources delivers the collection of information as full text databases, e-journals, image collections, multimedia in the form of $\mathrm{CD}$, tape, internet, web technology etc. E-resources may include e-journals, e-discussions, e-news, data archives, e-mail on line chatting, etc can be called as an e-resources. Electronic information source are a wide range of products going from 
electronic periodicals to CD-ROMs, from mailing list to databases, all of them having a common feature of being used and some time modified by a computer.

\section{3. about Annamalai University}

The Annamalai University is a unitary, teaching and residential university. It was founded by the munificence of the farsighted and noble hearted philanthropist and patron of letters the late Hon'ble Dr. Rajah Sir Annamalai Chettiar of Chettinad, Kt, LL.D., D.Litt. He started several colleges and ultimately the University in 1929. Since its inception, it has progressively tried to realize the aims of the noble Founder Pro-Chancellor. After him, his illustrious son Padma Bhushan Dr. Rajah Sir Muthiah Chettiar of Chettinad, was the Pro-Chancellor from 1948 to 1984 and he sedulously nurtured the growth and development of the University. The present Pro-Chancellor Dr.M.A.M. Ramaswamy, a philanthropist and a patron of sports, is the distinguished son of Dr.Rajah Sir Muthiah Chettiar. The University has had the unique good fortune of having a succession of eminent Vice-Chancellors to guide its destinies. During the last ten years the University has grown rapidly and consolidated its position as a unitary and residential University with Forty nine Departments of Study and over 2500 members on its teaching staff. Annamalainagar is already a busy and full-fledged University town east of Chidambaram, the abode of Lord Nataraja. The University campus, including the colleges, hostels and playgrounds occupies an area of about thousand acres.

\section{Review of Literature}

The importance and wide ranging scope of electronic resources for general communication, information retrieval and instructional delivery to support teaching and research activities in tertiary educational institutions is acknowledged world wide. The literature also shows that a number of relevant studies have been carried out on the use of e- resources by lecturers, research scholars and students worldwide. General user opinion towards the use of electronic resources, in particular CD-ROM, has been positive, with students enjoying using these sources and finding relatively few problems while using them (Ray and Day, 1998) ${ }^{5}$. This is clearly confirmed in the case of a survey undertaken at Oakland University by (Milne, 1998) ${ }^{6}$ into students' satisfaction with CD-ROMs.

Ali $(2005)^{7}$ found out that $83 \%$ of students surveyed felt that using this source saved them time, and found it relatively easy to use. Two thirds of those surveyed stated that if the CD-ROM was busy, they would wait for it to become free rather than use the print tool. However, a study of online searching of scientific information in science and technology libraries of Delhi reveals a sizeable number of users (almost $60 \%$ ) are facing numerous problems while browsing electronic information, such as lack of knowledge about the resources, lack of trained staff and inadequate terminals).

Studies have also been carried out on the use of electronic resources by teachers, students and research scholars of universities and research organizations. Seventy-eight percent $(78 \%)$ of the respondents feel that the use of the UGC Infonet e-journals has created high dependency value on their research work and they needed current article alert services and electronic document supply services (Madhusudhan, 2008).

In the context of developing countries, Okello-Obura and Magara (2008) ${ }^{9}$ investigated electronic information access and utilization at the East African School of Library and Information Science, Makerere University, Uganda. Out of the 250 targeted students, 190 responded, giving a response rate of $76 \%$. The study revealed that users derived a lot of benefits from electronic resources gaining access to a wider range of information and improved academic performance as a result of access to quality information.

Kebede $(2002)^{10}$ carried out a survey of the use of ICTs in ten African Public Library Services. The survey found that, although most libraries had internet connectivity, very few were offering web-based information services to their users. The study however, identifies four barriers to the effective provision of electronic resources in those libraries, namely: lack of strategic planning: lack of adequate or reliable funding; lack of use of Internet to provide information services to users and a lack of consistent training for users in new ICT services.

In the Nigerian context, Oduwole and Akpati (2003) ${ }^{11}$ investigated the accessibility and retrieval of electronic information at the University of Agriculture Library, Abeokuta, Nigeria. The 425 participants responded out of a survey population of 1,000 , giving a response rate of 53.87 percent. The study revealed that electronic information cuts across all members of the University community that it was to a greater extent easy to use and were satisfied with their search outputs. The constraints identified included insufficient number of terminals available for use despite high demand and inadequate electricity supply.

Ojo and Akande (2005) ${ }^{12}$ in a survey of 350 respondents examined students access, usage and awareness of electronic information resources at the University College Hospital (UCH) Ibadan, Nigeria. The study revealed that the level of usage of the electronic information resources is not high. A major problem however identified is lack of information retrieval skills for exploiting electronic resources, thus making the level of usage of resources by medical students very low.

Jagboro $(2003)^{13}$ had also emphasized the emerging reliance and attitude of users to electronic resources. In a study she conducted in some Nigerian Universities, it was found that $45.2 \%$ of respondents accessed electronic resources from cybercafés. Though this attitude, according to her is due to the proximity of cybercafés to user facilities.

Ajuwon $(2003)^{14}$ also carried out a study of uptake of ICTs by health science students at the University College Hospital, Ibadan. This study found that $57 \%$ of students sampled could 
not use a computer, that the use of the database was poor, due to lack of awareness, lack of access to computers, insufficient training and the high cost of provision.

In effect, all the studies reviewed above are implemented on the assumption that uptake of electronic resources is highly desirable in that it leads to increased productivity of work, learning, teaching and research.

\section{Significance of the Study}

In the present era of information explosion-more and more publications are becoming Web-concerned. Most of the social science libraries have changed the contemporary outlook towards functions and services. The environment is rapidly changing to an electronic one. The investigators decided to conduct this study for measuring the usage of e-resources by Researchers and Post-Graduate Students in Faculty of Arts, Annamalai University.

\section{Objectives of the Study}

The main objectives of the present study are as follows:

1. To find out the awareness of users' about available e-resources.

2. To study the purpose and utilization of e-resources.

3. To find out the frequency of using e-resources.

4. To find out the hindrances and problems faced by the users while accessing and using e-resources.

5. To study the level of satisfaction of users about availability and coverage of e-resources.

6. To study the preferred format for using e-resources.

7. To study the satisfaction level of users about infrastructure to support the access of e-resources.

8. To suggest suitable recommendations to improve facilities and services related to the use of e-resources.

\section{Methodology}

Keeping in view the above objectives in mind, a structured questionnaire was prepared to collect data from the users of e-resources in the Faculty of Arts, Annamalai University. Questionnaire contains various questions pertaining to the awareness and use of e-resources. For this purpose a total of 200 questionnaires were distributed among Researchers and Post-Graduate Students of the Faculty of Arts. Out of 200 questionnaires distributed, 180 valid questionnaires were collected and then data was analysed, tabulated, interpreted and presented in form of this paper.

\section{Scope and Limitation}

The present study covered the Research Scholars and Post-Graduate Students in the Faculty of Arts, Annamalai University. The Faculty of Arts includes eleven departments i.e. English, History, Political Science and Public Administration, Economics, Sociology, Commerce, Business Administration, Library and Information Science, Population Studies, Philosophy and Centre for Rural Development.

\section{Data Analysis}

Analysis of data is the ultimate step in research process. It is the link between raw data and significant results leading to conclusions. This process of analysis has to be result oriented.

\subsection{Population Study}

Table 1. Sex wise distribution of Respondents

\begin{tabular}{|c|c|c|}
\hline Gender & $\begin{array}{c}\text { No. of Respon- } \\
\text { dents }\end{array}$ & Percentage \\
\hline Male & 128 & 71.11 \\
\hline Female & 52 & 28.89 \\
\hline Total & 180 & 100.00 \\
\hline
\end{tabular}

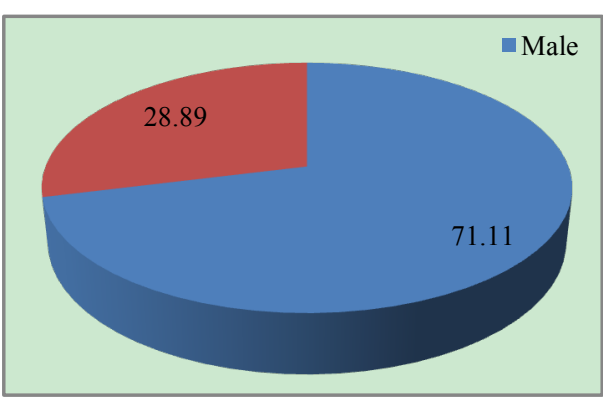

Figure 1. Sex wise distribution of Respondents

Personal detail section of the questionnaire provides information regarding the sex and different qualifications as can be seen from Table-1. It is shown in table-1, $71.11 \%$ of population studied were males and only $28.89 \%$ of total were females, who can use e-resources available through library for different purposes.

Table 2. Category wise distribution of Respondents

\begin{tabular}{|c|c|c|}
\hline Academic Status & No. of Respondents & Percentage \\
\hline Post Graduate Students & 106 & 58.88 \\
\hline Research Scholars & 74 & 41.12 \\
\hline Total & 180 & 100.00 \\
\hline
\end{tabular}

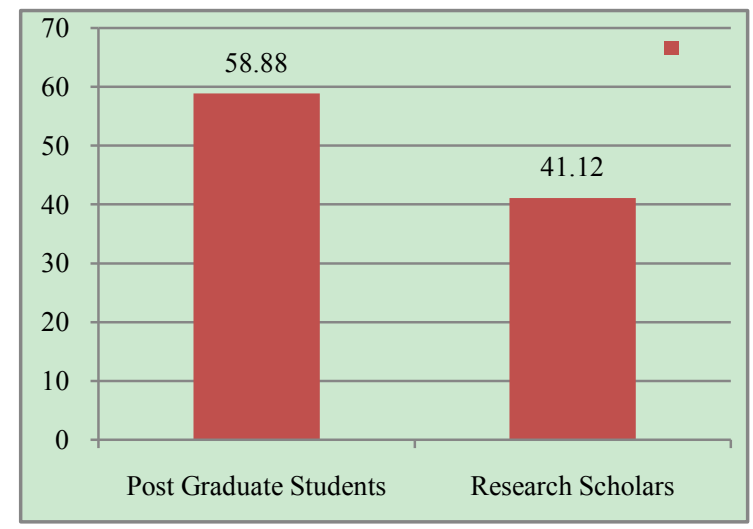

Figure 2. Category wise distribution of Respondents 
Table- 2 shows that $58.88 \%$ of the respondents were post graduate students and $41.12 \%$ were research scholars.

\subsection{Awareness about E-resources}

Table 3. Awareness about E-resources

\begin{tabular}{|c|c|c|}
\hline Gender & Aware & Not Aware \\
\hline Male & $116(90.62 \%)$ & $12(9.38 \%)$ \\
\hline Female & $42(80.76 \%)$ & $10(19.24 \%)$ \\
\hline Total & $158(87.77 \%)$ & $22(12.23 \%)$ \\
\hline
\end{tabular}

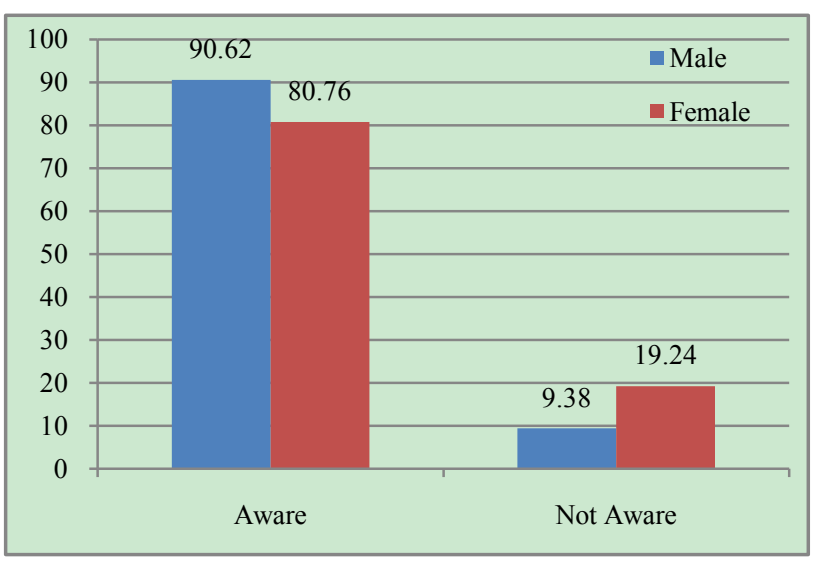

Figure 3. Awareness about E-resources

Table-3 shows the awareness of e-resources among the respondents available through the library $90.62 \%$ of the male users were aware about the e-resources whereas only $80.76 \%$ of female respondents were aware about the availability of e-resources. It can be seen that male respondents are more aware about e-resources than females.

\subsection{Preference Level of Using E-resources}

Table 4. Preference level of using E-resources

\begin{tabular}{|c|c|c|}
\hline Type & Number & Percentage \\
\hline Electronic & 86 & 47.78 \\
\hline Print & 59 & 32.78 \\
\hline Both & 35 & 19.44 \\
\hline Total & 180 & 100.00 \\
\hline
\end{tabular}

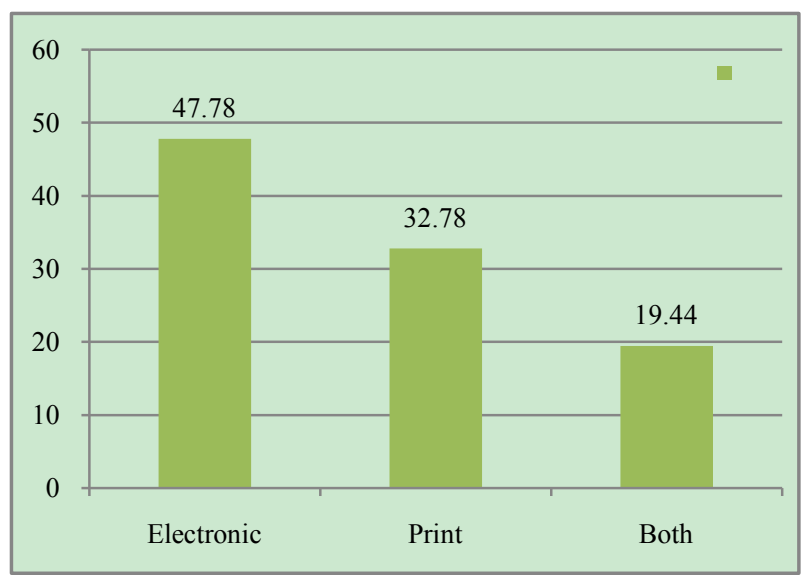

Figure 4. Preference level of using E-resources

The result reveals that $47.78 \%$ of respondents want to access only electronic version of information whereas only $32.78 \%$ users want to read the printed version of information but $19.44 \%$ respondents want to use both electronic and printed information.

\subsection{Frequency of Using E-resources}

Table 5. Frequency of using E-resources

\begin{tabular}{|c|c|c|}
\hline Duration & Number & Percentage \\
\hline Daily & 42 & 23.34 \\
\hline Weekly twice & 38 & 21.12 \\
\hline Weekly & 88 & 48.88 \\
\hline Monthly & 12 & 6.66 \\
\hline Total & 180 & 100.00 \\
\hline
\end{tabular}

In response to the question how frequently do you use e-resources? The respondents have responded in different ways (Table-5) Majority of respondents used e-resources weekly $(48.88 \%)$, daily $(23.34 \%)$ and weekly twice $(21.12 \%)$. Only few respondents (6.66) used e-resources monthly.

\subsection{Purpose of Using E-resources}

Table 6. Purpose of using E-resources

\begin{tabular}{|c|c|c|}
\hline Purpose & Number & Percentage \\
\hline For studying course work & 112 & 62.22 \\
\hline For update subject knowledge & 81 & 45.00 \\
\hline For teaching & 42 & 23.33 \\
\hline For research work & 93 & 51.66 \\
\hline For writing papers & 138 & 76.66 \\
\hline Any other works & 29 & 16.11 \\
\hline
\end{tabular}

Note: Total sample exceeds the required size since the questions are multiple choices

From the table- 6 , it is clear that most of the respondents $76.66 \%$ use e-resources for writing papers. $62.22 \%$ of respondents use e-resources for studying their course work and $51.66 \%$ respondents use for research work. $45 \%$ of respondents use e-resources for update subject knowledge and $23.33 \%$ of users using e-resources for teaching and only $16.11 \%$ respondents use e-resources for other works like exams etc.

\subsection{Methods of Learning E-resource Usage Skills}

Table 7. E-resource Usage Skill learning Method

\begin{tabular}{|c|c|c|}
\hline Method & Number & Percentage \\
\hline Training from the University & 94 & 52.23 \\
\hline Self study / Instruction & 42 & 23.33 \\
\hline From Friends & 36 & 20.00 \\
\hline External Sources & 8 & 4.44 \\
\hline Total & 180 & 100.00 \\
\hline
\end{tabular}

Table -7 shows more than half $(52.23 \%)$ acquired their online journal usage skill through training from the university, 23.33\% learned from self study, 20\% learned from friends. Only $4.44 \%$ acquired skills from external sources. 


\subsection{Location for Accessing E-resources}

Table 8. Location for accessing E-resources

\begin{tabular}{|c|c|c|}
\hline Location & Number & Percentage \\
\hline Central Library & 133 & 73.88 \\
\hline Department Library & 91 & 50.55 \\
\hline Computer Center & 68 & 37.77 \\
\hline Other Places & 45 & 25.00 \\
\hline
\end{tabular}

Note: Total sample exceeds the required size since the questions are multiple choices

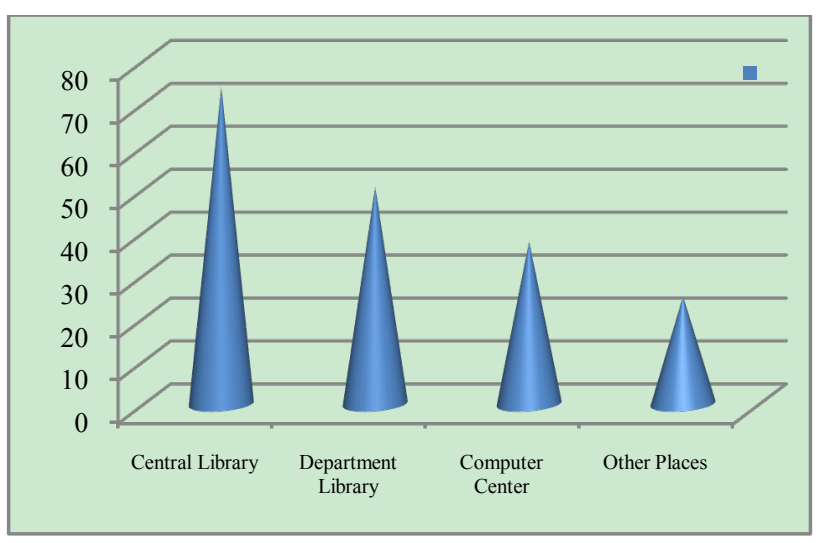

Figure 5. Location for accessing E-resources

When respondents were asked to indicate the preferred location to access e-resources. It is observed from the study of table- 8 shows that $73.88 \%$ of the respondents chose the central library, about $50.55 \%$ accessed at the department library, $37.77 \%$ accessed at the computer center and $25 \%$ accessed from other place where they got facility to access e-resources.

\subsection{Linking Pattern of E-resources}

Table 9. Linking Pattern of E-resources

\begin{tabular}{|c|c|c|}
\hline Linking & Number & Percentage \\
\hline Links through library website & 105 & 58.33 \\
\hline Links through publisher's website & 45 & 25.00 \\
\hline Links through Search Engines & 61 & 33.88 \\
\hline Links through E-resources website & 93 & 51.66 \\
\hline
\end{tabular}

Note: Total sample exceeds the required size since the questions are multiple choices

Table-9 shows how respondents search e-resources. Many of the respondents search e-resources through linking facility available on the library website as well as many through library website followed by e-resources websites. Some of them also link through search engines and publisher's website.

\subsection{Use Pattern of E-resources}

Table 10. Use Pattern of E-resources

\begin{tabular}{|c|c|c|}
\hline Use Pattern & Number & Percentage \\
\hline On computer screen & 87 & 48.33 \\
\hline Download in storage devices & 127 & 70.55 \\
\hline Take Printout & 98 & 54.44 \\
\hline
\end{tabular}

Note: Total sample exceeds the required size since the questions are multiple choices
Respondents were asked to indicate how they use the content of e-resources? It was observed from analysis that the majority $70.55 \%$ download the content in storage devices. $54.44 \%$ of respondents take printout form e-resources and $48.33 \%$ of respondents use on the computer screen.

\subsection{Formats of E-resources}

Table 11. File Formats of E-resources

\begin{tabular}{|c|c|c|}
\hline File Formats & Number & Percentage \\
\hline HTML & 45 & 25.00 \\
\hline PDF & 116 & 64.44 \\
\hline No Preference & 19 & 10.56 \\
\hline Total & 180 & 100.00 \\
\hline
\end{tabular}

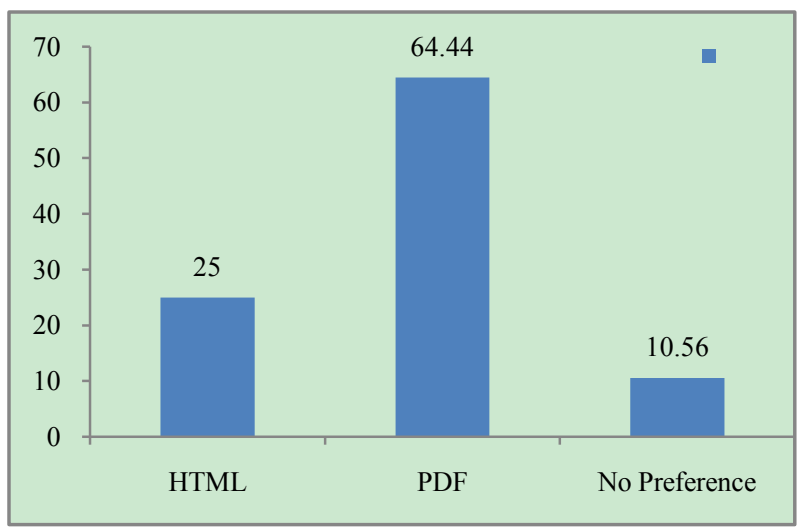

Figure 6. File formats of E-resources

E-resources are available in two major formats PDF and HTML. It was observed from the analysis that $64.44 \%$ of respondents preferred PDF format for using e-resources, whereas $25.00 \%$ of respondents preferred HTML format; and $10.56 \%$ have no preference.

\subsection{Difficulties of Accessing E-resources}

Table 12. Difficulties of Accessing E-resources

\begin{tabular}{|l|l|l|}
\hline Reasons & Number & Percentage \\
\hline $\begin{array}{l}\text { Not many E-resources available in my } \\
\text { subject }\end{array}$ & 108 & 60.00 \\
\hline $\begin{array}{l}\text { Coverage on E-resources is not suited to my } \\
\text { research area }\end{array}$ & 87 & 48.33 \\
\hline $\begin{array}{l}\text { No assistance provided by the information } \\
\text { professionals }\end{array}$ & 71 & 39.44 \\
\hline Lack of training & 64 & 35.55 \\
\hline Time consuming & 78 & 43.33 \\
\hline
\end{tabular}

Note: Total sample exceeds the required size since the questions are multiple choices

Though e-resources have become a common source among the academic and research communities, the majority of users stated that they have difficulties to use e-resources. The specific problems faced by the users are given in table-12. It was observed that majority of respondents are not satisfied with availability of enough e-resources in their respective subject followed by coverage of e-resources is not suited to my research area, time consuming, no assistance provided by the information professionals and lack of training. 


\subsection{Satisfaction of Accessing E-resources}

Table 13. Satisfaction of Accessing E-resources

\begin{tabular}{|c|c|c|}
\hline Level & Number & Percentage \\
\hline Highly satisfied & 91 & 50.56 \\
\hline Satisfied & 49 & 27.22 \\
\hline Average & 22 & 12.22 \\
\hline Not satisfied & 18 & 10.00 \\
\hline Total & 180 & 100.00 \\
\hline
\end{tabular}

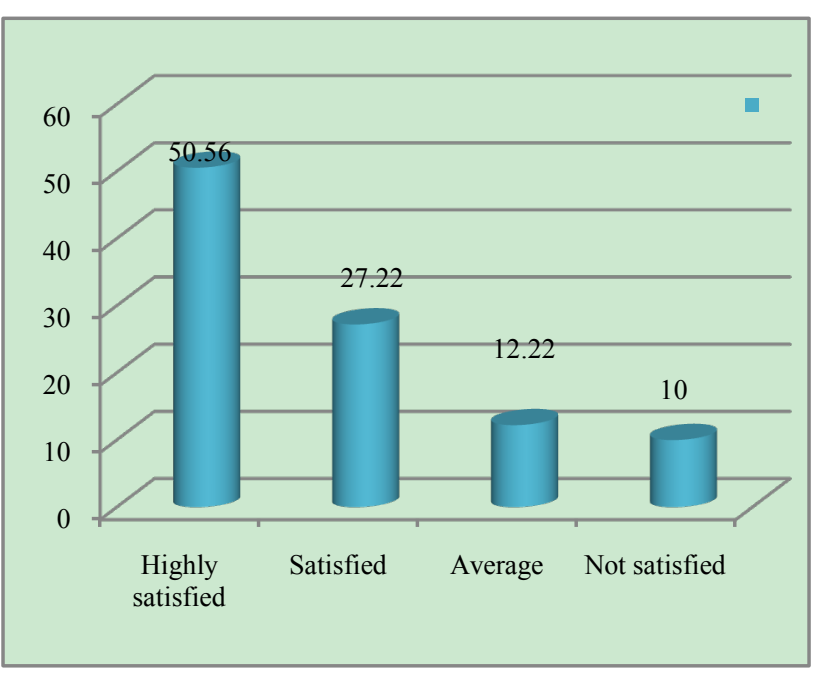

Figure 7. Satisfaction of Accessing E-resources

A question was asked to know the satisfaction level of infrastructure among the users for accessing e-resources. It was observed that majority $50.56 \%$ of respondents are highly satisfied with the infrastructure provided by the library for accessing e-resources at different levels whereas only $10 \%$ of respondents are not satisfied with the same.

\section{Recommendations}

This study showed that the uses of e-resources are very common among the research scholars and post graduate students of Faculty of Arts, Annamalai University. It also showed that majority of students and research scholars are dependent on e-resources to get desired and relevant information. It was however, revealed that practical uses of e-resources are not up to the worth in comparison to investments made in acquiring these resources.

Moreover, infrastructure and training, programmes are essential for better use of electronic resources campus-wide. It is evident from the analysis that the availability of e-resources on the campus is almost sufficient for all the existing disciplines but that the infrastructure to use the resources is not adequate and is actually hindering the ability to meet the requirements of users. This observation is common to libraries and universities in developing countries as is observed by Ali (2005).

In order to improve the facilities and services for effective use of electronic resources, in the University of Lagos, a number of suggestions can be made.
User training is essential for the better use of electronic resources in the library since a good number of users are searching electronic literature on their own.

- Electronic resources users should be taught about advanced search strategies and the use of controlled vocabulary to make electronic search process much easier.

- The university management should provide funds for subscription to more electronic primary and secondary sources.

- The library should also identify the non-users of electronic resources and proper steps should be taken to convert them into potential users of the resources.

- Furthermore, since users are experiencing problems in gathering information, the most suitable measures should be taken to overcome this, such as increasing the number of terminals and printers.

An electronic document delivery should also be introduced into the library at the earliest opportunity. Moreover, instead of expecting users to accept whatever exists in the market, the right perspective is to know and provide whatever electronic resources suits users under their respective circumstances (Kebede 2002). The library management therefore needs to conduct user study programs to know more about electronic resource needs of users.

\section{Conclusions}

The fast growth of information and communication technologies and particularly internet and electronic resources have changed the traditional methods of research, storage, retrieval and communication of scholarly information. Now a day's internet has emerged as most powerful medium for storage and retrieval of information. In order to retrieve relevant information, users have to make use of different electronic and web resources. The study showed that the use of the electronic resources have created a great impact upon users of Annamalai University Central Library in their research and development works. The rapid developments in information communication technology have facilitated the convergence of new electronic devices and formats. Information has been embedded in a variety of ways and forms in various kinds of electronic resources. So far the systematic research has not been done in this area particularly in the use of on-line electronic resources among the users of Annamalai University Central Library. It is clear from the study that the younger generation has accepted the electronic resources, but the volume of frequent usage of e-resources among the users have been found to be optimum level. Many of the respondents are unaware and have not used On-line thesis/dissertations, abstracts/indexes, OPAC, On-line databases, which are very relevant for their study and research. So the library can take initiatives to organize orientation programmes and user awareness programme in this area. 


\section{REFERENCES}

[1] Sharma, Chelan (2009) :Use And Impact of e-Resources at Guru Gobind Singh Indrapratha University (India): A case study Electronic Journal of Academic and Special Librarianship Vol. 10 no. 1: $1-8$.

[2] Ani, Okon E. and Ahiauzu, B. (2008). Towards effective development of electronic information resources in Nigerian University Libraries. Library Management 29(6/7): 504 514.

[3] Dadzie, P. S. (2005). Electronic Resources: access and usage at Ashesi University College. Campus - wide Information Systems 22(5) Available at: http//www.emeraldinsight.com. Accessed on 8th November, 2011.

[4] Naidu, GHS, Rajput, Prabhat and Motiyani, Kavita (2007). Use of Electronic Resources and services in University Libraries: A study of DAVV Central Library, Indore, In: NACLIN p. $309-319$.

[5] Ray, K. and Day J. (1998). Student attitudes towards electronic information resources. Information Research Vol.4 no. 2. Available at: http://informations.net/ir/4-2/paper 54.html. Accessed 8th November, 2011.

[6] Milne, Patricia (1998). Electronic access to information and its impact on scholarly communication.

[7] Ali, Naushad (2005). The use of electronic resources at IIT Delhi Library; a study of search behaviours. The Electronic Library Vol.23 no. 6: 691 - 700

[8] Madhusudhan, M. (2008). Use of UGC infonet - journals by the Research Scholars of University of Delhi”, Library Hi
Tech, Vol. 26. No. 3. pp. $369-386$.

[9] Okello-Obura, C and Magara, E. (2008). Electronic Information access and utilization by Makerere University in Uganda" Available at: http;//creative commons.org/licenses/by/2-0. Accessed 8th November, 2011.

[10] Kebede, G. (2002). The changing information needs of users in electronic environments. The Electronic Library, Vol. 20. No. 1: $19-21$

[11] Oduwole A. A. and Akpati, C. B. (2003). Accessibility and retrieval of Electronic Information at the University of Agriculture Library Abeokuta, Nigeria 52(5): 228 - 233, Available at: http://www.emeraldinsight.com/researchregiste r. Accessed 8th November, 2011.

[12] Ojo, R. A. and Akande, S. O. (2005). Students Access, Usage and awareness of Electronic Information Resources at the University College Hospital, University of Ibadan, Nigeria. Lagos Journal of Library and Information Science 3(1): 16 24.

[13] Jagboro, K.O. (2003): A study of Internet Usage in Nigerian Universities: A case study of Obafemi Awolowo University, Ile - Ife, Nigeria. First Monday, Vol8. No. 2. (Available at: http://Firstmonday.Org/Issues/Issue8_2/Jagboro/Index.html (8th November, 2011).

[14] Ajuwon G. A (2003). Computer and Internet Use by First Year Clinical and Nursing students in a Nigerian Teaching Hospital. BMC Medical Informatics and Decision Making, Vol.3 no. 10 September, Available at Biomed central, 1472-6947/3/10 (accessed: 8th November, 2011). 